\title{
Salinity on the germination of seed and index of germination speed of three ornamental species ${ }^{(1)}$
}

\author{
MARCOS VIEIRA FERRAZ ${ }^{(2)}$, CLAUDENIR FACINCANI FRANCO(3), GISELE SALES BATISTA ${ }^{(4)}$, \\ KATHIA FERNANDES LOPES PIVETTA ${ }^{(4)}$
}

\begin{abstract}
Salinity is a factor that interferes on seed germination in most species. The objective of this work was to study the effects of different concentrations of $\mathrm{NaCl}$ on the emergence and vigor of Petunia $\mathrm{x}$ hybrida, Torenia fournieri and Tagetes patula seedlings. The experimental design was entirely randomized with five treatments (five concentrations of $\mathrm{NaCl}: 0,25,50,75$ and $100 \mathrm{mM}$ ) and four replications of 50 seeds, for each species. The seeds were germinated in germitest paper at the alternating temperature of 20-30 ${ }^{\circ}$ C. Germination (\%) and Index of Germination Speed were performed daily until 14 days. Salt stress caused negative effects on the germination and IGS on seedlings of these three ornamentals species.
\end{abstract}

Keywords: salt stress, ornamental plants, physiological quality

\section{RESUMO}

Salinidade na germinação e índice de velocidade das sementes de três espécies ornamentais

A salinidade é um fator que interfere na germinação de sementes na maioria das espécies. O objetivo deste trabalho foi estudar os efeitos de diferentes concentrações de $\mathrm{NaCl}$ na emergência e vigor de plântulas de petúnia (Petunia x hybrida), torenia (Torenia fournieri) e marigold (Tagetes patula). O delineamento experimental utilizado foi inteiramente casualizado, com cinco tratamentos (cinco concentrações de $\mathrm{NaCl}:$ 0, 25, 50, 75 e $100 \mathrm{mM}$ ). O teste de germinação foi realizado com quatro repetições de 50 sementes, para cada espécie, dispostas em caixas do tipo "gerbox" e colocadas em papel germitest umedecidos nas temperaturas alternadas de 20 e $30^{\circ} \mathrm{C}$. O delineamento experimental foi inteiramente casualizado, com quatro repetições de 50 sementes. Os dados foram submetidos à análise de regressão. A porcentagem de germinação (\%) e o Índice de Velocidade de Germinação (IVG) foram avaliados diariamente durante 14 dias. O estresse salino provocou efeitos negativos na emergência e vigor de plântulas nas três espécies ornamentais.

Palavras-chave: estresse salino, plantas ornamentais, qualidade fisiológica

\section{INTRODUCTION}

The most important crops and vegetables are susceptible to salinity. The salinization process in agricultural fields will decrease the suitable land for cultivation by $30 \%$ within the next 25 years, and up to $50 \%$ by the year 2050 (BAHMANI et al, 2015).

Environmental stress like salinity limits plant growth and productivity all over the world. The world's land area affected by salinity stress is in the order of $7 \%$ in the total, which is equivalent to 930 million ha and the area is increasing (BIJANZADEH and KAZEMEINE, 2014).

The production of ornamental plants by seeds has grown considerably in Brazil. Along with that, there is an increasing demand for better quality of seeds and materials.

Germination is a critical stage in the life cycle of plants in saline environments and, wherein the soil is often subjected to high yield. At this stage, plants are more sensitive to environmental stress than the other phases. Environmental conditions of abiotic stress such as salinity, drought and temperature are currently the main factors that reduce crop productivity worldwide. These factors can act as stress leading to injury and in extreme cases, may result plant death (JALEEL et al., 2007).

The success of germination depends on the movement of water through the tissues surrounding the seed and the presence of salts affects the soil water potential, reducing the potential gradient between soil and seed surface, restricting water uptake by seeds (LOPES and MACEDO, 2008).

The high salt content in soil, especially sodium chloride $(\mathrm{NaCl})$, may inhibit germination, primarily due to the osmotic effect. In addition, the increase in salt concentration produces an increment in the percentage of abnormal seedlings due to the toxic action of salts on the seeds (LIMA et al., 2005).

The sensitivity of plant species to environments with high concentrations of salts in the soil, during the germination phase, may be critical to plant establishment (DITOMMASO, 2004).

The salinity of both soil and water is a major cause of falling yields (FLOWERS, 2004) due to the effects of

\footnotetext{
(1) Received in 22/07/2016 and accepted in 08/09/2016

${ }^{(2)}$ Universidade Estadual Paulista 'Júlio de Mesquita Filho' (FCA/UNESP), Departamento de Horticultura, Jaboticabal-SP, Brazil. *Corresponding author: ferrazmarcos@yahoo.com.br

(3) FATEC 'Nilo De Stéfani' (CEETEPS). Jaboticabal-SP, Brazil.

(4) Universidade Estadual Paul;ista ‘Júlio de Mesquita Filho’ (FCAV/UNESP), Departamento de Produção Vegetal. Jaboticabal-SP, Brazil.
} 
osmotic nature, toxic or nutritional (VIANA et al., 2004). However, the effects depend also on other factors such as species, cultivar, growth stage, types of salts, intensity and duration of salinity stress, cultural and irrigation management and climate conditions (TESTER and DAVENPORT, 2003).

Seed of Petunia x hybrida, Torenia fournieri. and Tagetes patula have been used for ornamental purposes in Brazil, both in the construction of plots of gardens as well as for use in pots and planters (LORENZI and SOUZA, 2008) by offering excellent beauty and diversity of colors. There is little information available in the literature on the effects of salt stress on the emergence and vigor of these ornamentals species.

Considering the importance of the salinity on the germination seeds, the objective of this study was to evaluate the effects of different concentrations of $\mathrm{NaCl}$ on the germination and IGS in Petunia x hybrida, Torenia fournieri and Tagetes patula seeds.

\section{MATERIAL AND METHODS}

Seeds of Petunia x hybrida Hort. ex. Vilm, Torenia fournieri Lind and Tagetes patula L. were used from commercial enterprise.

Initially, the moisture content in ornamental seeds was determined gravimetrically following oven drying at $103{ }^{\circ} \mathrm{C}$ for 17 hours (ISTA, 2009), and the electrical conductivity was measured in the five salt concentrations. The experimental design was completely randomized with five treatments (five concentrations of $\mathrm{NaCl}-0,25,50,75$ and 100 mmol.L $^{-1}$, with electrical conductivity of $0.65,2.15,4.31,6.32$ and 8.0 $\mathrm{dS} \mathrm{m} \mathrm{m}^{-1}$ respectively) and four replications of 50 seeds each, totaling 1000 seeds for each species.

Seeds were placed in gerbox boxes on germitest paper and maintained in BOD chamber at alternating temperature of 20 and $30^{\circ} \mathrm{C}$ with a photoperiod of 16 hours light and 8 hours of darkness, as recommended for these three ornamentals species in the Rules for Seed Analysis (BRASIL, 2009). Gerbox boxes were placed in bags of low density polyethylene, tied at the end with retread wire which was not allowed to lose moisture. The role germitest was moistened with saline solutions at a ratio of 2.2 times the weight of dry substrate, and the replacement of the solution was performed whenever needed by the method of weighing the substrate.

Assessments were made daily until 14 days, recording the seedlings emergency (E). The criterion adopted was the emergence of seedlings when the seedlings had shoot with size greater than or equal to $3 \mathrm{~mm}$ and its root protrusion of at least $2 \mathrm{~mm}$ and a perfect coleoptile, with a well-developed leaves (plumule) in or emerging from this, ignoring if the seeds did not germinate and abnormal seedlings with the malformed roots, necrotic, coleoptile empty, with broken or cracked primordial leaves along with abnormal or absent coleoptile.

Germination was calculated according to Maguire (1962), the formula $=$ IVE N1/D1 N2/D2 $++\ldots+\mathrm{Nn} /$ Dn, where: $=$ IGS speed rate of germination, $\mathrm{N}=$ number of seeds which computed from first to last count, $\mathrm{D}=$ number of days from sowing to first count. The data were submitted to analyze in SAS software; levels of salinity on the germination and index of emergence speed of these ornamentals species were processed by regression analysis.

\section{RESULTS}

There was statistical difference among the concentrations of $\mathrm{NaCl}$ for the variables germination and index of germination speed in each ornamental species studied. It was observed (Figure 1) linear decrease in germination and index of germination speed of seeds, with increasing concentration of salt solution. This means that these three species were very sensitive to salt. Salinity significantly affected the germination response of these ornamental seeds. 

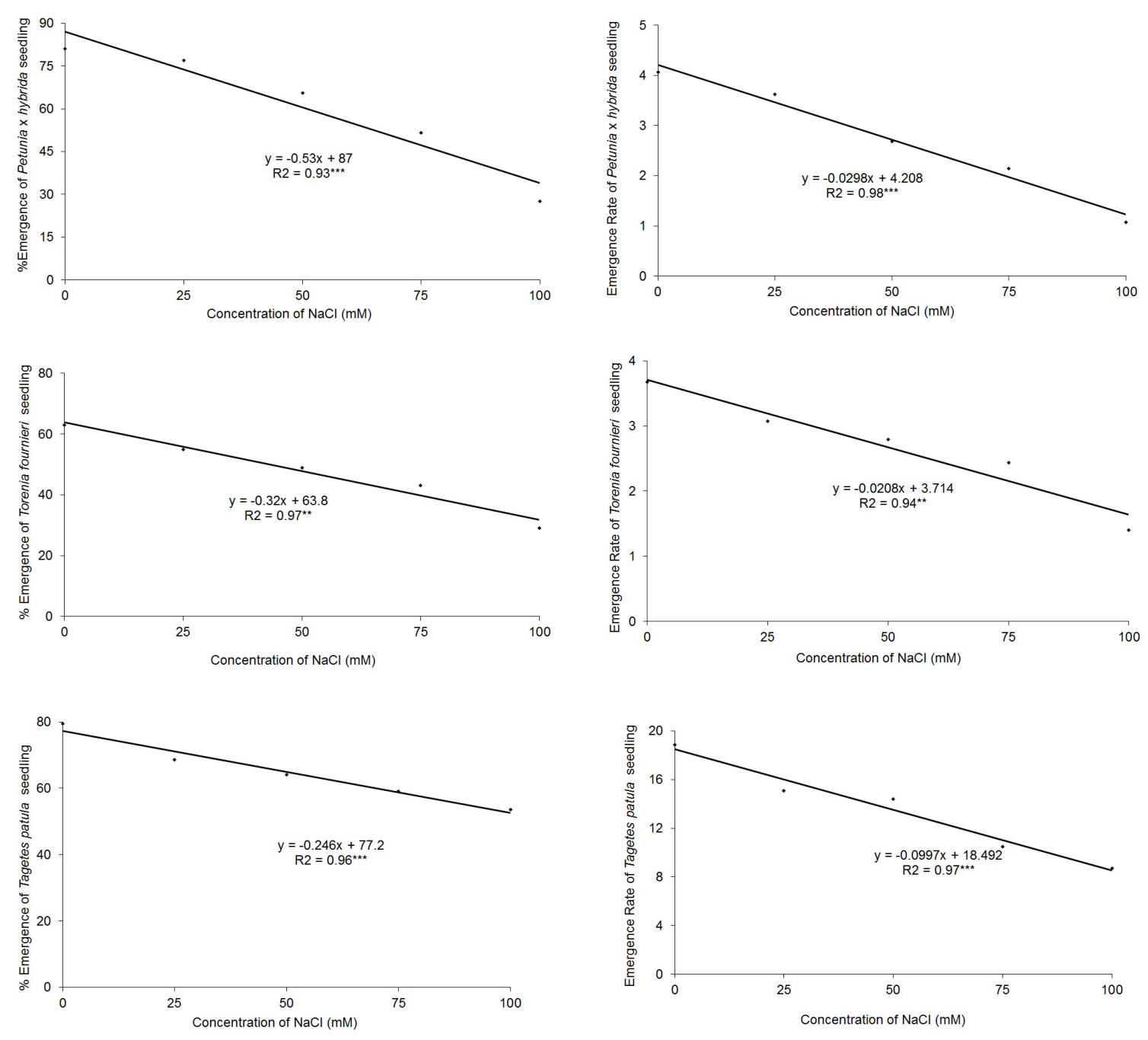

Figure 1. Germination (\%) and index of germination speed (IGS) under different concentrations of $\mathrm{NaCl}$.

The maximum emergence percentage for Petunia $\mathrm{x}$ hybrida was $81 \%$, while for Torenia fournieri and Tagetes patula, $63 \%$ and $79.5 \%$ respectively, all referring to the salt concentration of $0 \mathrm{mmol} . \mathrm{L}^{-1} \mathrm{NaCl}$ (electrical conductivity $0.65 \mathrm{dS} \mathrm{m}^{-1}$ ), occurring an emergency fall of $53.4 \%, 35 \%$ and $26 \%$ respectively, with increasing salt concentration. Tagetes patula seeds showed to be more salt tolerant than other ornamental seeds.
Seedlings of three ornamentals species emerged more slowly in that increased salt concentration, but Tagetes patula seedlings emerged in less time than the other species (Figure 2). It was observed that the distribution of IGS was heterogeneous among the ornamentals species and among salt concentrations (Figure 2). 

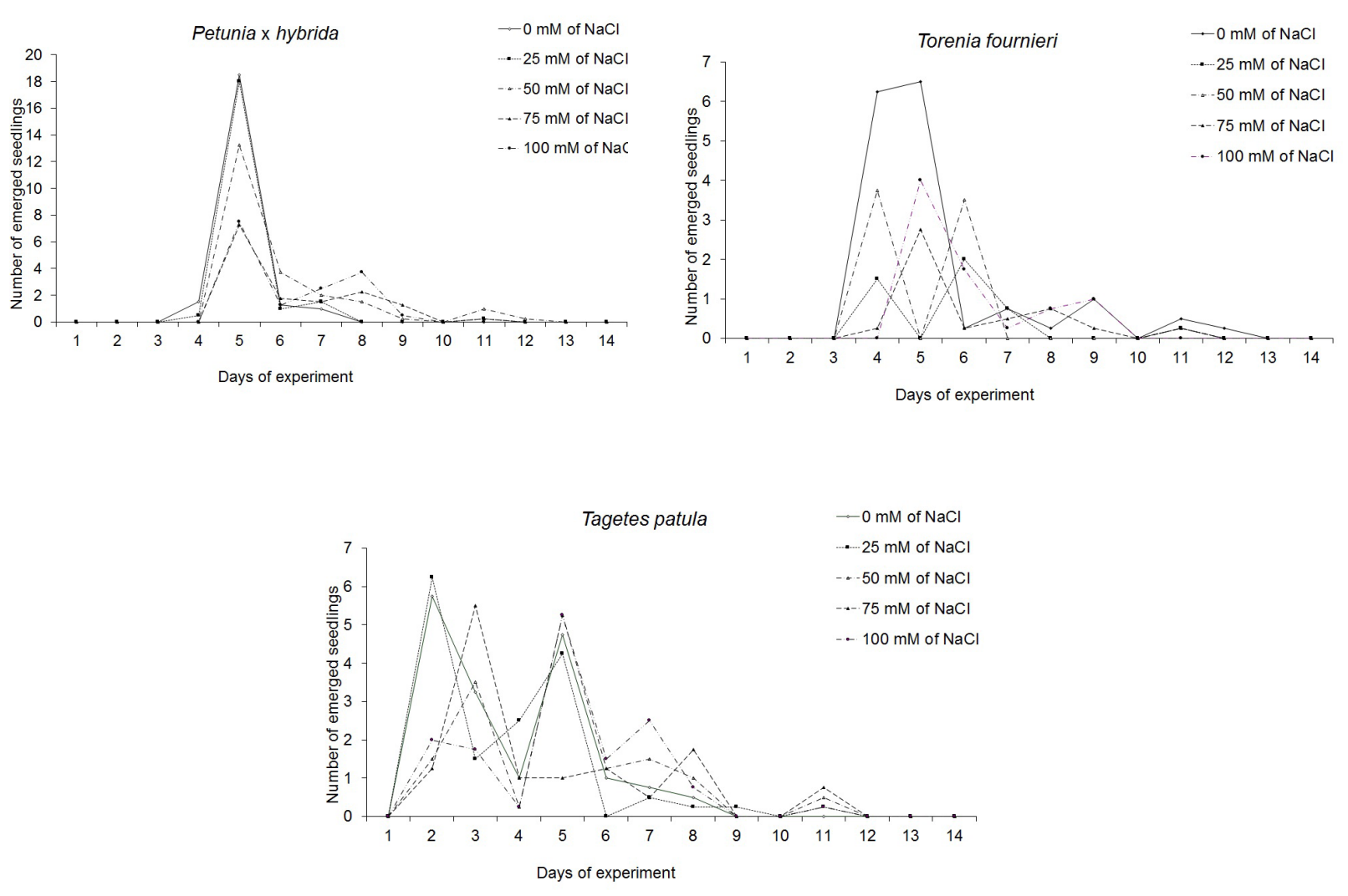

Figure 2. Emerged seedlings distributions under different concentrations of $\mathrm{NaCl}$ for 14 days evaluation.

\section{DISCUSSION}

Zapryanova and Atanassov (2009) studying the salinity of Tagetes spp. and Ageratum in cultivation in pots concluded that the salinity of the substrate inhibited the growth of these plants species. The inhibitory effect was best expressed in plants treated with $2 \% \mathrm{NaCl}$ and Tagetes spp. has being more tolerant. The increase in concentration of $\mathrm{NaCl}$ results in reduction of the flowering period of 54 to 23 days in Tagetes spp. and from 71 to 28 days in Ageratum.

Excess soluble salts causes a reduction in soil water potential, leading to less capacity for water absorption by seeds. This reduction of water potential and toxic effects of salts initially interfere in the process of water absorption by seeds, affecting germination (CAVALCANTE and PEREZ, 1995). The high salt content in soil, especially sodium chloride $(\mathrm{NaCl})$, may inhibit germination, primarily due to the osmotic effect (FANTI and PEREZ, 1996). Also, the increase in salt concentration produces an increase in the percentage of abnormal seedlings due to the toxic action of salts on the seeds (CAMPOS and ASSUNÇÃO, 1990).

Decrease of germination percentage and germination rate is related to reduction in water absorption into the seeds at imbibition and seed turgescence stages (MOSTAFAVI, 2011).

Ornamental plants are classified depending on their salinity tolerance (MAZHER AZZA et al., 2007). The representative of the genus Dahlia spp., Lilium spp. and Rosa spp. (Above $2 \mathrm{dsm}^{-1}$ ) proved to be more sensitive to salt stress and species of Chrysanthemum spp. and Dianthus caryophyllus (over $6 \mathrm{dsm}^{-1}$ ) were tolerant (IVANOVA et al., 1999).

Zhou and Xiao (2010), studying the effects of specific ions on germination of sunflower seeds, concluded that seed germination is influenced not only by salt concentration (or osmotic potential), but also by the nature of ions in solution salt and their interactions.

\section{CONCLUSION}

Salt stress caused negative effects on germination and index of germination speed in these ornamentals species, affecting the development of normal seedlings and reducing their viability. 


\section{REFERENCES}

BAHMANI, K.; NOORI, S.A.S.; DARBANDI, A.I.; AKARI, A. Molecular mechanisms of plant salinity tolerance: a review. Australian Journal of Crop Science. v.9, n.4, p.321-336, 2015.

BIJANZADEH, E.; KAZEMEINI, S.A. Tissue architecture changes of expanding barley (Hordeum vulgare L.) leaf under salt stress. Australian Journal of Crop Science. v.8, n.10, p.1373-1379, 2014.

BRASIL. Ministério da Agricultura e Reforma Agrária. Regras para análise de sementes. Brasília: Secretaria Nacional de Defesa Agropecuária, p. 395, 2009.

CAMPOS, I.S.; ASSUNÇÃO, M.V. Efeito do cloreto de sódio na germinação e vigor e plântulas de arroz. Pesquisa Agropecuária Brasileira, v.25, n.6, p.837-843, 1990.

CAVAlCANTE, A.M.B.; PEREZ, S.C.J.G.A. Efeitos dos estresses hídrico e salino sobre a germinação de sementes de Leucaena leucocephala (Lam.) Witt. Pesquisa Agropecuária Brasileira, v.25, n.2, p.281-289, 1995.

DITOMMASO, A. Germination behavior of common ragweed (Ambrosia artemisiifolia) populations across a range of salinities. Weed Science, v.52, n.6, p.1002-1009, 2004. DOI: 10.1614/WS-04-030R1

FANTI, S.C.; PEREZ, S.C.J.G.A. Efeitos de estresse hídrico e salino na germinação de Bauhinia forficata Link. Revista Ceres, v.43, n.249, p.654-662, 1996.

FLOWERS, T.J. Improving crop salt tolerance. Journal of Experimental Botany, v.55, p.307-319, 2004.

ISTA. International Rules For Seed Testing. International Seed Testing Association, Switzerland, Chapter 9, p.1-20, 2009.

IVANOVA, V.; PANAYOTOV, N.; IVANOVA, I. Effect of saline soil conditions on the decorative and vegetative behavior of Chrysanthemum indicum L. Dahlia Greidinger International Symposium Nutrient Management under Salinity and Water Stress. Technion - Israel Institute of Technology Haifa, Israel 1-4 March 1999. p. 441-444, 1999.
JALEEL, C.A.; GOPI, R., MANIVANNAN, P.; PANNEERSELVAM, R. Antioxidative potentials as a protective mechanism in Catharanthus roseus (L.) G. Don. plants under salinity stress. Turkish Journal of Botany, v.31, p.245-251, 2007.

LIMA, M.G.S.; LOPES, N.F.; MORAES, D.M.; ABREU, C.M. Qualidade fisiológica de sementes de arroz submetidas a estresse salino. Revista Brasileira de Sementes, v.27, n.1, p. 54-61, 2005.

LOPES, J.C.; MACEDO, C.M.P. Germinação de sementes de couve chinesa sob influência do teor de água, substrato e estresse salino. Revista Brasileira de Sementes, v.30, n.3, p.79-85, 2008.

LORENZI, H.; SOUZA, H.M. Plantas Ornamentais do Brasil: arbustivas, herbáceas e trepadeiras. 4 ed., Nova Odessa: Instituto Plantarum, 2008. 1120p.

MAGUIRE, J.D. Speed of germination aid in selection and evaluation of seedling emergence and vigor. Crop Science, v.2, n.1, p.176-177, 1962.

MAZHER AZZA, A.M.; FATMA, E.; QUESNI ET.; FARAHAT, M. World Journal of Agricultural Sciences, v.3, n.3, p.386-395, 2007.

MOSTAFAVI, K.; SADEGHI GEIVE, H.; DADRESAN, M.; ZARABI, M. Effects of drought stress on germination indices of corn hybrids (Zea mays L.). International Journal of AgriScience, vol.1, p.10-18, 2011.

TESTER, M.; DAVENPORT, R. $\mathrm{Na}^{+}$tolerance and $\mathrm{Na}^{+}$ transport in higher plants. Annals of Botany, v.19, p.503527, 2003.

VIANA, S.B.A.; FERNANDES, P.D.; GHEYI, H.R.; SOARES, F.A.L., CARNEIRO, P.T. Índices morfofisiológicos e de produção de alface sob estresse salino. Revista Brasileira de Engenharia Agrícola e Ambiental, v.8, p.23-30, 2004.

ZAPRYANOVA, N.; ATANASSOVA, B. Effects of salt stress on growth and flowering of ornamental annual species. Biotechnology \& Biotechnological Equipment, v.23, n.2, p.177-179, 2009.

ZHOU, D.; XIAO, M. Specific ion effects on the seed germination of sunflower, Journal of Plant Nutrition, v.33, n.2, p.255-266, 2010. 